\title{
MIĘDZY NATURALIZMEM A RELIGIĄ. O IDEI SPOŁECZEŃSTWA POSTSEKULARNEGO W MYŚLI JÜRGENA HABERMASA
}

Rafał Wonicki

Uniwersytet Warszawski

Od zamachu na World Trade Center we wrześniu 2001 roku możemy zauważyć rosnące zainteresowanie badaczy zachodnich kwestiami religii. Również Jürgen Habermas, bodaj najsławniejszy żyjący dziś filozof niemiecki, zaczął szukać odpowiedzi na pytania o rolę religii i tradycji oświeceniowej oraz ich wzajemne relacje w świecie Zachodu. Pytania, które wcześniej w jego rozważaniach się nie pojawiały. Od tego czasu napisał kilka ciekawych tekstów na temat roli religii w sferze publicznej. W języku polskim ukazały się jak dotąd dwie najważniejsze jego prace dotyczące tej tematyki i obrazujące zmianę akcentów w poglądach frankfurckiego filozofa i socjologa, tak zdecydowanie od lat broniącego oświeceniowej tradycji rozumu. Pierwsza praca to Prayszłosśc natury ludžkiej (Habermas 2003) z dodaną mową wygłoszoną 14 października 2001 roku w kościele św. Pawła we Frankfurcie z okazji otrzymania Nagrody Pokojowej Stowarzyszenia Księgarzy Niemieckich „Wierzyć i wiedzieć”. Druga to opublikowana przez wydawnictwo PWN w 2012 roku książka Międsy naturalizmem a religia.

Niniejszy tekst pomyślany jest jako wprowadzenie do poglądów Habermasa w kwestii wzajemnych relacji rozumu i wiary oraz idei społeczeństwa postsekularnego. Ma na celu przedstawienie najważniejszych argumentów autora Teorii driałania komunikacyjnego oraz uchwycenie ewentualnych trudności w proponowanym podejściu. Zacznijmy od tego, co autor Filozoficznego dyskursu nowoczesności rozumie przez pojęcie postsekularyzmu. W „Wierzyć i wiedzieć” pisze, że społeczeństwo postsekularne to takie społeczeństwo, „gdzie w otoczeniu wciąż podlegającym sekularyzacji nadal 
istnieją wspólnoty religijne" (Habermas 2003: 105). Habermas wyciaga z tego faktu dwa wnioski. Po pierwsze, że sekularyzacja nie prowadzi do osłabienia religii, i po drugie, że wzrost ważności religii nie zagraża procesowi sekularyzacji. Choć między tymi dwoma wnioskami może pojawić się napięcie, to obywatele muszą uznać je za współwystępujące we współczesnych społeczeństwach. Religie nie przestały bowiem istnieć w świecie zachodnim wraz z nadejściem oświecenia. Nie nastapiła pełna sekularyzacja, czy też mówiąc inaczej, laicyzacja albo zeświecczenie społeczeństwa na skutek krytyki klasycznej metafizyki, odkryć naukowych czy dominacji empirycznego, nominalistycznego i scjentystycznego nastawienia. Religie, a wraz z nimi wiara, że istnieją rzeczy niepoznawalne na drodze empirycznej i sensualnej nie przestały istnieć, jak postulował sekularyzm. Obecnie wciąż bowiem obserwujemy żywotność wspólnot religijnych na świecie (np. duża liczba Kościołów w USA czy napływ wiernych do Kościoła katolickiego w Afryce $)^{1}$. Habermas zatem, uwzględniając fakt istnienia religii i wiedzy naukowej, światopoglądu religijnego i światopoglądu laickiego, próbuje znaleźć w ramach swojej teorii deliberatywnego państwa prawa wspólną płaszczyznę do dialogu między nimi. Uznaje on, że nie powinno być tak, by Kościół walczył ze scjentyzmem, a przedstawiciele nauki konkurowali z, ich zdaniem, nieracjonalnym światopoglądem religijnym. Wzajemna walka jest niewłaściwym rozpoznaniem przez obie strony współczesnej rzeczywistości społecznej, która jest rzeczywistościa postsekularna. W tak zdefiniowanym jak powyżej postsekularnym społeczeństwie Habermas przyznaje zdrowemu rozsądkowi (common sense) rolę mediatora między nauką a religia. Zdrowy rozsądek dla niego to część świata życia, świata przeżywanego. W ramach zachodniego common sense'u mamy tendencję do życia w zgodzie z naukowym widzeniem świata, ale jednocześnie jego częścia jest zbiór kulturowych, społecznych i religijnych wyobrażeń człowieka o samym sobie. Zdrowy rozsądek nie może więc, z powodów normatywnych, podporządkować się zupełnie deterministycznej wizji świata tworzonej przez naukę. Stracilibyśmy wtedy moralny i polityczny punkt odniesienia, a tym samym możliwość opisu tego, czego chcemy i do czego powinniśmy dążyć jako jednostki i wspólnoty. Oprócz narracji wyjaśniającej wciąż przecież odwołujemy się w świecie społecznym do rozumienia i usprawiedliwiania albo uprawomocniania naszych czynów zgodnie z kulturowymi czy aksjologicznymi wzorcami. Zarazem zdrowy rozsądek w teorii Habermasa jest

\footnotetext{
${ }^{1} \mathrm{Na}$ efekt odradzania się religii mają według Habermasa wpływ przynajmniej trzy elementy: po pierwsze, działalność misyjna kościołów, po drugie, powstawanie nowych religijnych ruchów, i po trzecie, polityczna instrumentalizacja religii (zob.: Habermas J., Notes on a post secular society, http://www.signandsight.com/features/1714.html; dostęp: 21.02.2013).
} 
opisany jako sposób myślenia racjonalnych podmiotów, które uznają się za autonomiczne i tym samym dystansują się od religii. Dlatego też zdrowy rozsądek przeciwstawia tradycji religijnej i naukowej własną perspektywę opisu. Jest to perspektywa będąca częścią ludzkiej samowiedzy, której nie można zredukować do religii albo do nauki i która zachowuje do nich dystans. Tak rozumiany zdrowy rozsądek ma swoje odzwierciedlenie w regułach państwa liberalnego. Oczywiście z perspektywy liberalnej jedynie te religie zasługują na miano racjonalnych, które nie zmuszają swoich wyznawców do praktyk niezgodnych z podstawowymi wartościami liberalnymi. Wyznawcy tych religii $\mathrm{w}$ ramach historycznych procesów uczenia się musieli, jak zakłada Habermas (2003: 106), „uporać się z poznawczym dysonansem, jakim jest zetknięcie $z$ innymi wyznaniami i religiami [...] dostosować się do autorytetu nauk, które mają społeczny monopol na wiedzę o świecie" oraz „uznać przesłanki państwa konstytucyjnego, oparte na moralności świeckiej”. Spełnienie tych warunków gwarantowało im sukces adaptacyjny w pluralistycznym i zliberalizowanym nowoczesnym społeczeństwie. Jednak patrząc na stale odradzające się spory o początek i koniec życia, inżynierię genetyczną czy ostatnio emocjonujące Polaków spory o związki partnerskie, widać, że fakt pluralizmu światopoglądowego oraz pluralizmu religijnego jest czymś wciąż trudnym do zaakceptowania dla wierzących i niewierzacych obywateli w wielu krajach. Niebezpieczeństwo tych sporów polega na tym, że moga one doprowadzić do zerwania społecznej więzi solidarności między członkami wspólnoty politycznej. Habermas widzi to niebezpieczeństwo i przyjmuje podwójna strategię, by mu zapobiec. Po pierwsze, rekonstruuje historyczne relacje między religia, filozofią i etyka, a po drugie, wskazuje na proces uczenia się i wzajemnego przenikania tych dyskursów. Jego celem jest odsłonięcie normatywnych zasad demokratycznego państwa prawa pozwalających twierdzić, że liberalne państwo jest neutralne i nie faworyzuje żadnej ze stron sporu, a wręcz ułatwia im wzajemną koegzystencję (zob. także Habermas 2005). W kwestii podwójnej strategii, a przede wszystkim rekonstrukcji historycznych relacji między filozofią i religia Habermas (2012) w tekście Przedpolityczne podstany demokratycznego państwa praworzadnego przypomina, że religia i filozofia przenikały się i inspirowały nawzajem od dawna. Filozofia przyswoiła sobie chrześcijańskie treści, co można dostrzec choćby w przekładzie religijnej idei stworzenia człowieka na podobieństwo Boga na sekularną ideę godności wszystkich ludzi (Habermas 2012: 99). Jest to zdaniem autora pozytywny przykład translacji języka religijnego na język świecki. Pokazanie możliwości takiej translacji jest według niego potrzebne, by z jednej strony, 
dowartościować wspólnoty religijne, a z drugiej, nie odrzucać wartości liberalnej demokracji. Habermas zarazem, oceniając proces kolonizacji świata życia jako niszczący więź obywatelskiej solidarności, uznaje, że w demokratycznym państwie prawa należy docenić ważność wspólnot religijnych $\mathrm{w}$ reprodukcji wartości i podstaw spajających społeczeństwo. Dlatego też chce pokazać, jakie warunki muszą być spełnione, by wierzący i niewierzący członkowie liberalnej wspólnoty politycznej współżyli ze sobą w harmonii i zgodzie. Takimi warunkami sa: wzajemne uznanie się przez wierzących i niewierzących za równych w prawach współobywateli, wzajemna tolerancja dla swoich światopoglądów oraz brak możliwości wykluczenia z góry określonych argumentów, ponieważ nawet argumenty formułowane w języku religijnym mogą mieć racjonalną zawartość. Wykluczenie zaś czyjegoś uczestnictwa i możliwości wypowiedzi przed dyskusją na dany temat przeczyłoby formalnym warunkom dyskursu praktycznego (moralnego i etyczno-politycznego) opisywanego przez Habermasa w jego pracach, w ramach którego wszystkie potencjalnie zainteresowane strony muszą zostać w dyskusji uwzględnione i mieć możliwość zajęcia stanowiska na tak lub nie. Biorąc to wszystko, co do tej pory zostało powiedziane, pod uwagę, wydawać by się mogło, że uwzględnienie religii w procesie dyskursywnego dochodzenia do porozumienia nie jest aż tak istotną zmiana w stosunku do głoszonych wcześniej przez Habermasa poglądów. Warto jednak podkreślić i docenić, że choć w swoich wcześniejszych rozważaniach nie brał on pod uwagę argumentów religijnych, to obecnie uznaje, że „[z]sekularyzowani członkowie społeczeństwa, jeśli wchodzą w swoje role obywateli państwa, nie mogą ani zasadniczo odmawiać potencjału prawdziwościowego religijnym obrazom świata, ani odmawiać wierzącym współobywatelom prawa do wyrażania w języku religijnym swojego zdania w publicznych dyskusjach" (Habermas 2012: 101). Oczywiście w swojej idei świeckiego demokratycznego państwa Habermas odwołuje się do Kantowskiego założenia o racjonalnych i autonomicznych podmiotach, dla których religia staje się przedmiotem racjonalnego uprawomocnienia. Dlatego też religijne dyskursy obowiązuje wymóg translacji na język zlaicyzowanego prawa. Zarazem jednak ze względu na religijno-historyczne korzenie sekularnego państwa nie może ono dyskredytować znaczenia religii jako czynnika wspierającego określone wartości w państwie. Przeciwnie, religia, jeśli tylko jest możliwa do przetłumaczenia na język świeckich wartości, stanowi źródło sensów, które dodatkowo mogą spajać wspólnotę. Tak więc sekularyzacja nie jest dla Habermasa związana z odrzuceniem i zanikiem religii, ale raczej zamienia się w postsekularyzm, 
czyli proces translacji dyskursu religijnego na język świecki. Dzięki temu zabiegowi religia może być kompatybilna z liberalnymi oświeceniowymi wartościami (liberalizm i chrześcijaństwo promują na przykład ideę godności człowieka). W ten sposób, szukając wspólnej płaszczyzny między wiarą i rozumem, autor chce, jak się wydaje, ocalić ideę oświecenia i wskazać, że w świecie postsekularnym obie strony - wierzący i niewierzący by współżyć ze sobą w zgodzie, muszą dokonać wysiłków w modyfikacji swoich stanowisk epistemicznych. Aby to unaocznić, przywołuje przykłady empiryczne majace dowodzić, że wytworzenie przez wiernych akceptacji dla liberalnych wartości jest możliwe. Nie oznacza to jednak, że niewierzący obywatele nie muszą dokonywać wysiłku wydobycia z treści religijnych treści poznawczych. Wręcz przeciwnie. Nie mogą bowiem traktować religii w społeczeństwie postsekularnym jako jedynie jakiegoś anachronicznego wierzenia. Po stronie niewierzących, w imię komplementarnego procesu uczenia się, powinno pojawić się poważne potraktowanie argumentów religijnych w debacie publicznej. Stojąc zatem na straży politycznej integracji, Habermas krytykuje nie tylko fundamentalizm religijny, ale również naturalizm i scjentyzm, które mają tendencję do redukowania poprawnych wnioskowań do zdań empirycznie obserwowalnych, co odbiera wartość wypowiedziom nie tylko religijnym, lecz także moralnym i prawnym ${ }^{2}$. Podejście scjentystyczne odrzuca bowiem wszelką metafizykę, w tym metafizykę religijna. Z kolei $\mathrm{w}$ społeczeństwie postsekularnym, z jakim na Zachodzie mamy do czynienia, powinny dominować postawa i światopogląd postmetafizyczny, który „przyjmuje wobec religii postawę gotowości do nauki i zarazem agnostycyzmu. Respektuje różnicę między przekonaniami opartymi na wierze a roszczeniami do obowiązywania, które podlegaja publicznej krytyce" (Habermas 2012: 126). Tak więc w postulowanym przez Habermasa społeczeństwie postsekularnym obywatele wierzący ucza się od niewierzących tego, co jest możliwe do przełożenia na język prawa, a niewierzący od wierzących tego, że wartości liberalne są do pogodzenia z religijnymi szerokorozległymi doktrynami.

\footnotetext{
${ }^{2}$ Powyższy fragment świadczy o tym, że Habermas widzi zagrożenie dla sfery publicznej nie tylko ze strony fundamentalizmu religijnego, ale również ze strony naukowego naturalizmu, który odrzucił en block wszystkie formy religijnego myślenia jako archaiczne. Dopóki zaś sekularyści będą uznawać religię za archaiczną formę ideologii, która nie może niczego wartościowego wnieść do zsekularyzowanego demokratycznego społeczeństwa, dopóty nie będzie można mówić o sensownej dyskusji między religią i rozumem (zob. więcej: Habermas 2012: 213). Jeśli przedstawiona tu interpretacja jest poprawna, to wydaje się, że Habermas dokonuje przynajmniej dwóch uproszczeń. Po pierwsze, zrównuje scjentyzm z sekularyzmem, a po drugie, zrównuje scjentyzm z naturalizmem. W obydwu wypadkach taki redukcjonizm może budzić wątpliwości.
} 
Warto w tym miejscu zwrócić uwagę, że Habermas dostrzega w samym procesie przekładu zarówno element pozytywny - możliwość adaptacji religii - jak i element negatywny, związany z uprzywilejowaniem rozumu oświeceniowego wobec myślenia religijnego. Dzięki możliwości translacji twierdzeń religijnych na język niereligijny określone konsekwencje etyczne i zbiory norm moralnych moga zostać zaakceptowane przez ludzi różnych wyznań oraz osoby niewierzące. Jednakże transformacja ta nie powinna podporządkować religii autorytetowi rozumu zsekularyzowanego. Twierdzenia religijne potrzebuja takiego przekładu po to, aby zostały uznane przez inne światopoglądy za równoprawne, ale nie oznacza to, że muszą podporządkować się bezwzględnie i koniecznie rozumowi. Habermas tworzy możliwość włączenia się ludzi wierzących w racjonalne dyskursy bez deprecjonowania z góry jakiejkolwiek ze stron. Taka racjonalna dyskusja jest, jego zdaniem, możliwa, gdy wszystkie jej strony zgodza się wcześniej na pierwszeństwo demokratycznych założeń o równości i autonomii podmiotów jako prawodawców. Dlatego też należy na nowo przemyśleć, czy często przyjmowane za oczywiste uprzywilejowanie rozumu w stosunku do wiary, przejęte z dziedzictwa oświeceniowego, nie zaburza równowagi między wierzącymi i niewierzącymi. I to jest chyba największa zmiana w dotychczasowym stanowisku Habermasa. W odpowiedzi stwierdza bowiem, że rozum nie może osądzać ważności żadnej religii, choć nie oznacza to zarazem, że autor rezygnuje z nadrzędności komunikacyjnego procesu dochodzenia do porozumienia. Rozum nie może służyć co prawda jako środek do uprawomocnienia jakiejkolwiek religii, ale ma służyć rozróżnianiu wiedzy od wiary. Choć więc religia ma równe prawo do bycia częścia racjonalnego dyskursu, powinna być przetłumaczona na język zsekularyzowanych pojęć. Wyznawcy danej religii nie moga zatem być wykluczeni z publicznej debaty nad kwestiami etycznymi czy moralno-politycznymi, ale język religii nie może być też już częścia sformalizowanej opinii publicznej, takiej jak parlament, gdzie debatuje się i uchwala prawa dla całej społeczności. Innymi słowy, „w parlamencie porządek obrad musi zapewniać marszałkowi prawo do tego, by usuwać z protokołu religijne treści i uzasadnienia. Prawdziwościowy potencjał wypowiedzi religijnych nie zostaje utracony $\mathrm{z}$ punktu widzenia zinstytucjonalizowanej praktyki doradczej i decyzyjnej, jeśli wymagany przekład zostaje dokonany w przestrzeni przedparlamentarnej, a więc na poziomie politycznej sfery publicznej" (Habermas 2012: 117). Habermas nawiązuje w tym miejscu do idei rozumu publicznego, czyli argumentów, które maja być z założenia możliwe do zaakceptowania przez wszystkich. Jest to 
założenie filozoficznie uprawomocniające władzę państwową niezależnie od religijnych form legitymizacji państwa; założenie, które pozwoliło w nowożytności na dokonanie rozdziału Kościoła od państwa i które wciąż w demokracjach liberalnych w świecie zachodnim jest co do zasady uznawane. Współcześnie państwa liberalne w celu uniknięcia wojen religijnych wciąż w swojej większości uznają bowiem neutralność światopoglądową władz za wartość, a także, w ramach swoich rozstrzygnięć normatywnych, wspieraja procedurę demokratycznej legitymizacji, tak by obywatele jako równi w prawie, niezależnie od ich szerokich rozległych doktryn metafizycznych, mieli możliwość współdecydowania o kształcie i kierunku polityki rządu. Zachodnie państwa typu liberalnego stoją na straży religijnego pluralizmu i wolności sumienia, czyli zasad, które wszyscy obywatele wzajemnie powinni akceptować. Jeśli zaś jakieś ogólne zasady konstytucyjne regulujące postępowanie obywateli wierzących i niewierzących są narzucone przez jedną ze stron, łamiąc w ten sposób regułę konsensusu komunikacyjnego, to stają się nieprawomocne. Habermas na gruncie swojej teorii mówi o tym w ten sposób: „Członkowie demokratycznej wspólnoty winni są wzajemnego podawania uzasadnień, gdyż jedynie dzięki temu panowanie polityczne może przestać być czymś represyjnym” (Habermas 2012: 109). Choć więc instytucje władzy powinny być neutralne światopoglądowo, to nie wynika z tego założenia, aby wierzacy obywatele musieli kierować się w swoich decyzjach laickimi kryteriami (Habermas 2012: 114). Co więcej: „Liberalne państwo nie może przemieniać koniecznego instytucjonalnego rozdziału religii i polityki w nieadekwatne do sytuacji mentalne i psychologiczne brzemię narzucone na wierzących. Musi jednak oczekiwać z ich strony uznania dla zasady panowania neutralnego światopoglądowo. Każdy musi wiedzieć i akceptować to, że powyżej progu instytucjonalnego, który oddziela nieformalną sferę publiczną od parlamentów, sądów, ministerstw i ciał administracyjnych, liczą się tylko argumenty laickie" (Habermas 2012: 115). Cytat ten dość jasno pokazuje, że Habermas nie zmienił swoich poglądów aż tak bardzo, jakbyśmy mogli się spodziewać.

Podsumowując powyższe rozważania, można powiedzieć, że w sytuacji pluralizmu światopoglądowego i postsekularyzmu obywatelom państwa liberalnego powinno zależeć na dopuszczeniu wielości głosów do politycznej sfery publicznej, gdyż w przeciwnym razie społeczeństwo może zostać pozbawione „ważnych sensotwórczych zasobów” (Habermas 2012: 115). Sensy te na poziomie instytucjonalnym można przekładać na język ogólnodostępny, a więc laicki, bez obawy, że zostanie utracony jakiś 
prawdziwościowy potencjał wypowiedzi religijnych. Jeśli jednak taki przekład się nie powiedzie, to treści religijne nie mogą znaleźć odzwierciedlenia w projektach ustaw.

$\mathrm{Na}$ koniec tego krótkiego tekstu wprowadzającego w ideę społeczeństwa postsekularnego w myśli Habermasa można pokusić się o postawienie kilku pytań do zreferowanych powyżej poglądów. Pierwsze jest takie, czy Habermas nie zaciera granicy między opisem społeczeństwa postsekularnego a jego normatywna projekcja, tak jak to sam zarzucał sekularystom. Po drugie, czy w jego teorii religia nie została zredukowana do roli jednego z możliwych sposobów bycia w świecie, stając się jedynie pewnym wyborem i sprawa prywatną zarazem, co dla wierzących może być poglądem nie do zaakceptowania. Po trzecie, czy dokonując przekładu języka religii na język etyki, nie tracimy mimo wszystko ważnych sensów w niej zawartych. I wreszcie czy Habermas nie jest zbyt idealistyczny, zakładając w swojej teorii liberalnego państwa demokratycznego zdolność obywateli do wykraczania poza swoje światopoglądowe granice. Sam Habermas uznaje, że warunkiem powodzenia zaistnienia postsekularnego społeczeństwa jest gotowość dwóch stron do redefinicji myślenia o roli religijnych i niereligijnych światopoglądów. Dlaczego jednak niereligijni obywatele mieliby uznać, że przekazy religijne są sensowne, i odwrotnie, dlaczego religijni obywatele mieliby uznać, że argumenty laickie maja pierwszeństwo ze względów normatywnych a nie czysto pragmatycznych, siłowych czy sytuacji typu modus vivendi. Przyjęta przez Habermasa strategia odwołania się do common sense' $u$ w celu rozwiązania napięcia między religia a nauką wydaje się jednak podobna do proponowanej przez niego wcześniej postawy postkonwencjonalnej, odrzucającej zarówno Objawienie, jak i myślenie naukowe jako coś z góry danego. Definiowany i projektowany $\mathrm{w}$ ten sposób common sense wydaje się więc bardzo elitarny i osiagalny wciąż dla niewielu obywateli demokratycznych państw świata zachodniego. Zarazem jednak sama próba zmierzenia się przez Habermasa z fenomenem religii i teoriami sekularyzacji powoduje, że wymagający czytelnik otrzymuje rozważania pobudzające go do stawiania pytań dotyczacych natury relacji między rozumem a wiarą czy podstaw dialogu między obywatelami wyznającymi różne światopoglądy w spluralizowanym społeczeństwie oraz dobry punkt wyjścia do szukania na nie własnych odpowiedzi. 
Bibliografia:

/// Bhargava R. red. 1998. Secularism and its Critics, Oxford University Press, Delhi.

/// Habermas J. 2003. Prayszłość natury ludzkiej, tłum. M. Łukasiewicz, Scholar, Warszawa.

/// Habermas J. 2005. Faktyczność $i$ obowiazywanie, tłum. A. Romaniuk, R. Marszałek, Scholar, Warszawa.

/// Habermas J. 2009. Europe: The Faltering Project, Polity Press, Cambridge, Malden.

/// Habermas J. 2012. Międý naturalizmem a religia, tłum. M. Pańków, Wydawnictwo Naukowe PWN, Warszawa.

/// Habermas J. et al., 2010. An Awareness of What is Missing: Faith and Reason in a Post-Secular Age, Polity Press, Cambridge, Malden.

/// Habermas J. Notes on a post secular society w: http://www.signandsight. com/features/1714.html; dostęp: 21.02.2013.

/// Ratzinger J., Habermas, J. 2006. Dialectics of Secularization: On Reason and Religion, Ignatius Press, San Francisco.

/// Veer van der P., Lehmann H. red. 1999. Nation and Religion: Perspectives on Europe and Asia, Princeton University Press, Princeton.

/// Warner M. et al., red. 2010. Varieties of Secularism in a Secular age. Harvard University Press, Cambridge-London.

\section{/// Abstrakt}

Niniejszy tekst pomyślany jest jako wprowadzenie do poglądów Habermasa w kwestii wzajemnych relacji rozumu i wiary oraz idei społeczeństwa postsekularnego. Ma on na celu przedstawienie najważniejszych argumentów autora Teorii dzৃiałania komunikacyjnego oraz uchwycenie ewentualnych trudności w proponowanym przez Habermasa podejściu. Zdaniem niemieckiego myśliciela sekularyzacja nie prowadzi do osłabienia religii, a wzrost ważności religii nie zagraża procesowi sekularyzacji. Autor zatem, uwzględniając fakt istnienia religii i wiedzy naukowej, światopoglądu religijnego i światopoglądu laickiego, próbuje znaleźć, w ramach swojej teorii deliberatywnego państwa prawa, wspólną płaszczyznę do dialogu 
między nimi. Jest nią zdrowy rozsądek (common sense), który pełni w jego teorii społeczeństwa postsekulanego rolę mediatora między nauką a religia.

Słowa klucze:

sekularyzm, postsekularyzm, Habermas, religia, społeczeństwo postsekularne, sfera publiczna, zdrowy rozsądek

\section{/// Abstract}

The article is written as the introduction to Habermas' views on mutual relation between reason and faith and to his idea of post-secular society. Its main aim is to reconstruct the main thesis of the author of "Theory of Communicative Action" and to grasp potential difficulties in his approach. According to Habermas secularization does not lead to the weakening of the religion and increase of the validity of religion does not threaten the process of secularization. Thus, including the fact that region and secular outlooks co-exist he tries to find the common background which enable the dialog between them. In order to do it he refers to the theory of deliberative constitutional state claiming that the common sense can play in the postsecular societies the role of the mediator between the science and religions' point of view.

Keywords:

Secularism, Postsecularism, Habermas, Religion, Post-secular Society, Public Sphere, Common Sense 